\title{
The Association between Education and Income and Health in a Developing Country: Do We Measure Perception or Reality?
}

\author{
Suni Petersen* \\ Ladan Khatijibah, Alliant International University, USA
}

Submission: August 09, 2018; Published: August 30, 2018

*Corresponding author: Suni Petersen, Ladan Khatijibah, Alliant International University, USA, Email: spetersen@alliant.edu

\begin{abstract}
The salience of income and education on health may differ in resource-deficit environments. This study explored this relationship and its measurement in rural Vietnam. Participants were 343 women with education level of 5.1 grades and household incomes equaling $\$ 170 /$ month. Women were interviewed by trained indigenous women health advocates. Results indicated that the perception of income level is a better predictor of health than actual income. Education is not a significant predictor of health. Measures of perception of income were more important predictors than actual income. Actual disease burden was more effective than a brief, general measure of health.
\end{abstract}

Keywords: International; Health Perception and Income and Education; Vietnam; Indigenous Health Advocates; Developing World Income and Health

\section{Introduction}

Conducting research and designing interventions in the developing world pushes our methodologies and knowledge to its limits. Researchers make assumptions and create hypotheses based on the current literature, most of which has been conducted in the developed countries. When applying them to the developing world, these assumptions are often in advertently exported without being tested. One such assumption is the relationship between income, education, and health. In developed countries, this relationship is substantial [1]. The pathway between education and income to improved health is intertwined because both are highly correlated. The pathways, however, in a resource deficit environment, such as in the developing world, are more convoluted. The relationship between the two and its impact on health in the aggregate is supported but is not on individual levels in developing countries [2]. The purpose of this study was to explore this relationship and ways of measuring it. Measures with a history of use in a developing country typically emerge from studies conducted on majority populations in major cities. In Vietnam, only somewhat educated indigenous people speak the national language. Indigenous people unfamiliar with answering multiple choice or Likert scales, call into question the use of complex scales when simple questions may be sufficient. Therefore, medical and public health studies frequently use one question self-report statements. A few studies have used pictorial assessments to produce more valid research among indigenous people.

\section{Income, Education and Health}

In the developed world income has been a strong predictor of physical [3,4] and mental health [5] in developed country diseases such as cardiovascular disease [6], cancer [7], and diabetes [8]. In the developing world, parasitic and infectious diseases are responsible for the highest disease burden [9]. Only one study investigated conditions leading to helminths and parasites resulting in an association with environmental conditions and sanitation which result from poverty but not income or education directly [10]. There is little information on how income and education interact with the conditions that lead to parasitic disease or incidence of parasites in developing countries. Education and income are measures of status in the developed world. But in countries that do not operate as meritocracies, education and income are less important in determining status than heritage. In some developing countries, income levels are adjusted by the government so that income does not reflect the position or the education required to function in that position. An underground system of favors and services enhance income. In a resource-deficit environment, only a few may have access to health essentials. Under these conditions, neither objective nor subjective perceived income nor education may be predictive of health status. To the degree that income and education matter, designers of interventions that target parasitic disease rates must understand how these factors are associated with health. 
The pathway from education or income to disease burden due to parasites is complex. Parasitic disease contributes to financial hardship through malnutrition due to low-protein, iron and vitamins in individual's diet, along with inadequate health care, and poorer living conditions [11] and both income and education have an interactive effect of these conditions with childhood vaccines [12]. In the developed society, the empirical evidence suggests that education has a significant impact on health via mediating factors such as economic, social, interpersonal, health knowledge and behavior mediators [13]. These mediating factors equip individuals with the ability to access health care, engage in activities that promote wellbeing, and possess psychological and coping resources such as social support, stress management, and proper nutrition, in the developed world [14]. The benefit of education for women shows up when moving from primary to secondary education levels and for men when moving from secondary to post-secondary education levels. Among people in the developing world, where the norm is limited to only primary education, education may not hold any predictive power. Two studies in India and Kenya demonstrated that deworming children, while leading to better school attendance did not result in higher test scores [15]. Yet, height (presumably due to better health and nutrition) was positively correlated with education among adults in several South American countries [16]. And two other studies found no effects for education and health, one of which used the same methods as the Indian study [17]. Many people never go beyond 5th grade in rural Vietnam. If the point at which education begins to influence health practices occurs at higher levels, the advantage would not be seen. Those who do attain secondary or tertiary education levels seldom return to their villages due to lack of employment. While both education levels and income levels may vary somewhat even under these conditions, they may not vary together. In an investigation using mathematical modeling, Akguch (2010) demonstrated that different levels of education were associated with varying levels of income growth depending on the development levels of countries. In the least developed countries, growth in tertiary education seemed to benefit less than growth in primary education levels in the aggregate with more benefit derived from improving the quality. These studies suggest that there is no straightforward correlation between education and income across countries.

\section{Measuring Income, Education and Health}

Measuring income: Studies typically measure income categorically. Such measures may be subject to image management bias [18]. In countries in which image is a high value, such a method is likely to be inaccurate. The inaccuracies can be prevented through asking for an actual amount within the time space that people naturally consider, such as a presenttime orientation. In this study, actual income was measured by asking the amount earned by the entire household in one month. Individuals' personal beliefs about their social status are reliably and strongly related to their overall health. Two studies demonstrated that subjective SES was a better predictor of health in Britain [19] and in the US [20], all developing countries. In developing countries, hosting societies that value image, perception may be more important and may actually provide more variance in measurement than actual income. Nancy Adler et al. [21] developed a pictorial way of measuring subjective comparative social status that does not require language. The picture is a ladder, a concept understood in all societies, and asks the responder to mark the rung on which her family stands relative to her community.

Measuring Education: In rural Vietnam, the majority of participants have less than 5 th grade or a small percentage reaching 12 years, with no evidence of anything in between. The reason is twofold: for a student to continue in school, he/ she must pass a test and the family must have the income to send the child to another village to attend. Few current adults have had this advantage. Therefore, education should be measured in years of education, not levels. Measuring general health in selfreport studies. Developing world studies emerge from public health and typically use specific straightforward questions, often one or two questions asking the respondent to rate their or their family's health on a Likert scale. While broadly accepted, the measure is likely to be inaccurate due to optimism bias, image protection efforts and other unconscious processes influencing memory. Yet, if general health can be adequately measured using one sentence, it could lead to more studies being conducted in challenging environments.

\section{Methodology}

This study took place in remote areas of Central Vietnam and was part of a larger study testing an intervention. This study tested the following hypotheses: Perceived income levels will be significantly different than actual income level. A checklist of actual disease experience (FHQ) will be significantly different than perceived self-report measure of family health. Education and income will correlate and predict health status? Is actual or perceived income more predictive of health status? The study was approved by an ethical review board and the Vietnamese government. Informed consent was obtained.

\section{Participants}

Three hundred and forty-three women were recruited through the local Women's Union. Ages ranged from 20-67, $\mathrm{x}=$ 38 ( $s d=10.2$ ) in two villages. Ninety-four percent were married and living with their spouses. The majority of the husbands and wives worked at the same vocation. Sixty-six percent were farmers, $9 \%$ fishers, $3.9 \%$ were solely homemakers, and the rest were tradespeople, such as bricklayers and laborers. They had 5.5 years ( $\mathrm{sd}=3.1$ ) of school on average and household income was $\mathrm{x}=\$ 137$ (sd $=\$ 70$ ) / month for families of 4.3 people. These women had $x=2.8(s d=1.3)$ children per family, and their childrens' average age was $9.8(\mathrm{sd}=5.1)$. 


\section{Juniper Online Journal of Public Health}

\section{Measures}

All questionnaires were translated and back-translated into Vietnamese by a certified translator. The questionnaires were all answered using a trained health advocate in interviews.

Income: Income was measured in two ways, first, as an actual amount with the question asked, "How much money does your entire family earn in a month?" The second assessment of income was perceived comparative financial status within the community using Nancy Adler's 10 question subjective SES ladder which has been shown to be effective when assessing individuals' self-report of social status [22]. Respondents were asked, "Imagine that the rungs of this ladder represents your community with the top rung being those who have the most and the bottom rung being those who have the least. Put an $\mathrm{X}$ where you place your family financially."

Measuring Health: One question asking, "How do you rate your health overall?" The five point Likert scale was answered using $1=$ poor to $5=$ excellent. A second measure, the Family Health Questionnaire was also included. The FHQ, developed by the World Health Organization, measures 22 specific conditions ranging from menstrual cramps to heart disease. Four diseases were added because of their prevalence in the area in which data were gathered, malaria, dengue fever, typhoid, and cholera. The scale has three columns next to each disease in which a participant checks whether they were bothered "not at all (0)", "a little (1)" or "a lot (2)" by that ailment during the last month. Education was a straightforward question rather than asking about levels of schooling in order to obtain a figure that can be compared [23]. The question was, "How many years did you go to school?"

Procedures: Indigenous women who were trained as health advocates were each assigned 12 families from their own hamlet. The women's committee chose the families for the intervention. The Health Advocates used interviews to collect data to avoid asking about literacy. Although literacy level is reported at $89 \%$ for Vietnam by the government website, most women in the villages have a low language ability. As result, during the data collection, participants were sometimes assisted by the health advocate in understanding the questions. The health advocates were trained not to influence how the participant answered the question. The questionnaires were sent to the U. S. researcher to enter into SPSS and analyze and interpretation of data was conducted with the partner institutions in Vietnam [24].

\section{Results}

Using a one-sample t-test, findings indicated that there was a significant difference between perceived income levels and actual income $(\mathrm{t}=25, \mathrm{df}=168, \mathrm{p}<.000$. There was a dramatic and significant difference between using brief question and FHQ to measure health $(t=11.13, \mathrm{df}=343, \mathrm{p}<.000)$. A series of correlations were performed on measures of income coupled with measures of health. Actual income was modestly and negatively correlated with health measured by FHQ ( $r=-0.215$, $\mathrm{p}<.006)$ and perceived income was also negatively significantly correlated with health measured by FHQ $(r=-0.223, \mathrm{p}<.004)$. Both actual and perceived income levels were entered into a stepwise regression resulting in perceived income as the stronger predictor of health as measured by the FHQ (F ( df =158) $=8.9, \mathrm{p}<.003$ ). Perceived income level within the communities is more relevant in health research than actual income levels in rural Vietnam. Not surprisingly, when the same analyses were conducted using the one question rating scale, results were not significant, thus indicating that in measuring health, the actual disease-specific health information is a better practice than nonspecific general sense of health, while in measuring income levels, the relative measure is more important than actual measures of income $[25,26]$. There were no significant correlations between education and health regardless of how health was measured, either perceived or actual disease conditions. Additionally, education and income were both significantly correlated but these correlations are more modest than one would see in developed world research, with perceived financial status ( $\mathrm{r}=$ $.249, \mathrm{p}<.000$ ) more highly correlated with number of years in school than actual income levels $(r=.20, \mathrm{p}<.002)$.

\section{Discussion}

The practice of using one question to measure health in developing world research is relied upon because of the difficulties involved in translating measures and validating the constructs measured. However, this study suggests that there is danger in such a practice. This study demonstrates that the reliance on short-cut measures may be inaccurate and lead to faulty research. Furthermore, the measures that were most effective in this study were those that transcended language. The perceived income measure was pictorial. The findings in this study corresponds with prior research findings indicating that the higher individuals rated themselves in the social hierarchy, the better health they had (Adler \& Epel, 2000) as well. The best health measure was a list of illness conditions with the participant simply checking if they were bothered by that condition this month, none, a little, or a lot.

In a communal society, it is possible that the perceived standing would be held more important than actual income, especially since even those with higher income levels do not have appreciably different lives than others in the same village. It is also possible that education did not make a difference in health because we measured it by asking number of years in school and not by attendance within those years. In rural Vietnam, planting and harvesting supercedes regular school attendance. Parasitic disease rates are very high and interfere with attendance and children stay home to care for younger siblings while parents till the fields. Thus, education may matter more than is revealed in this study. Future research should include attendance and quality as well. Additionally, the resulting lack of significance could be due to the fact that most of the people did not go beyond primary school years and the difference in impact may not be realized until many more years of school are achieved. In rural 


\section{Juniper Online Journal of Public Health}

developing country areas, education is does not appear to be a factor due to low variance.

While education and income are strong correlates of health in developed countries, this link is questionable in developing world conditions. This study found a correlation between perceived and actual income with health, with perceived income being more relevant but did not find a significant association between education and health. Therefore, perception of income levels should be addressed in developing and testing interventions.

\section{Limitations}

As in many studies conducted in areas where indigenous languages and constructs blend with the national language, the way questions are asked impose a challenge. Testing populations that are unfamiliar with testing in general pose a problem that has not been studied. Future studies should focus on how indigenous populations comprehend various ways of asking questions in research. Another limitation is that this study did not use an objective measure of health such as testing for actual parasites. Education measure did not elicit information on school attendance where truancy is a common part of life.

\section{Implications and Conclusion}

When measuring income, perceived income appears to be either more understood or more predictive than actual income. Studies should not rely on one or two sentence general questions when asking about health. It appears that a very specific measure is required. In this study, the list of actual conditions and amount of discomfort was predictive. The findings of this study suggest that best practices in research include: use of pictorial relative measures with income, specific years in school and attendance for education, and specific disease conditions for general health.

\section{References}

1. Akguc M (2010) The Effects of Different Stages of Education on Income across Countries, iredu.u-ourgogne.

2. Adler NE, Epel ES, Castellazzo G, Ickovics JR (2000) Relationship of subjective and objective social status with psychological and physiological functioning: Preliminary data in healthy White women. Health psychology 19(6): 586-596.

3. Blakely TA, Kennedy BP, Glass R, Kawachi I (2000) What is the lag time between income inequality and health status? Journal of epidemiology and community health 54(4): 318-319.

4. Bobonis GJ, Miguel E, Puri Sharma C (2006) Anemia and school participation. Journal of Human Resources 41(4): 692-721.

5. Christenson BA, Johnson NE (1995) Educational Inequality in Adult Mortality: An Assessment with Death Certificate Data from Michigan. Demography 32(2): 215-229.

6. Cutler DM, Lleras Muney A (2010) Understanding differences in health behaviors by education. Journal of Health Economics 29(1): 1-28.

7. Cutler D, Lleras Muney A (2008) Education and Health: Evaluating Theories and Evidence. In J House, R Schoeni, G Kaplan, H Pollack eds Making Americans Healthier: Social and Economic Policy as Health Policy. New York: Russell Sage Foundation, USA.
8. Gamboa MI, Basualdo JA, Kozubsky L, Costas E, Cueto Rua E, et al. (1998) Prevalence of intestinal parasitosis within three population groups in La Plata, Argentina. European Journal of Epidemiology 14(1): 55-61.

9. Grantham McGregor S, Cheung YB, Cueto S, Glewwe P, Richter L, et al. (2007) International Child Development Steering Group Developmental potential in the first 5 years for children in developing countries. The Lancet 369(9555): 60-70.

10. Hu P, Adler NE, Goldman N, Weinstein M, Seeman TE (2005) Relationship between subjective social status and measures of health in older Taiwanese persons. Journal of the American Geriatrics Society 53(3): 483-488.

11. King CH (2010) Parasites and poverty: The case of schistosomiasis. Acta Tropica 113(2): 95-104.

12. Lynch SM (2003) Cohort and life course patterns in the relationship between education and health: A hierarchical approach. Demography 40(2): 309-331.

13. Mujahid MS, James SA, Kaplan GA, Salonen JT (2017) Socioeconomic position, John Henryism, and incidence of acute myocardial infarction in Finnish men. Social Science \& Medicine 173: 54-62.

14. Mashayekhi Ghoyonlo V, Kiafar B, Rohani M, Esmaeili H, Erfanian Taghvaee MR (2015) Correlation between Socioeconomic Status and Clinical Course in Patients with Cutaneous Leishmaniasis. Journal of Cutaneous Medicine \& Surgery 19(1): 40-44.

15. Miguel E, Kremer M (2003) Worms identifying impacts on education and health in the presence of treatment externalities. Econometrica 72(1): 159-217.

16. Nutbeam D (2000) Health literacy as a public health goal: A challenge for contemporary health education and communication strategies into the 21st century. Health promotion International 15(3): 259-267.

17. Miguel E, Glewwe P (2008) The impact of child health and nutrition on education in less developed countries. In TP Schultz and JA Strauss (Eds.); Handbook of Development Economics. Amsterdam North Holland 4: 3561-3606.

18. Oates Gabriela R, Jackson, Bradford E, Partridge, Edward E, et al (2017) Sociodemographic patterns of chronic disease: How the Midsouth region compares to the rest of the country. American Journal of Preventive Medicine 52(1 Suppl 1): S31-S39.

19. Operario D, Adler NE, Williams DR (2004) Subjective social status: Reliability and predictive utility for global health. Psychology \& Health 19(2): 237-246.

20. Patel V, Kleinman A (2003) Poverty and common mental disorders in developing countries. Bulletin of the World Health Organization 81(8): 609-615.

21. Singh Manoux A, Marmot MG, Adler N (2005) Does subjective social status predict health and change in health status better than objective status? Psychosomatic Medicine 67(6): 855-861.

22. Stronks K, van de Mheen H, Van Den Bos J, Mackenbach JP (1997) The interrelationship between income, health and employment status. International Journal of Epidemiology 26(3): 592-600.

23. Stuart JO, Windschitl P, Smith AR, Scherer AM (2017) Behaving optimistically: How the (un)desirability of an outcome can bias people's preparations for it. Journal of Behavioral Decision Making 30(1): 54-69.

24. Tracey TJG (2016) A note on socially desirable responding. Journal of Counseling Psychology 63(2): 224-232.

25. Vogl TS (2012) Education and health in developing countries.

26. Wang Y, Lopez JMS, Bolge SC, Zhu VJ, Stang PE (2016) BMC Psychiatry. BioMed Central Limited 16: 88. 
This work is licensed under Creative Commons Attribution 4.0 License DOI: 10.19080/JOJPH.2018.04.555631

\section{Your next submission with Juniper Publishers}

will reach you the below assets

- Quality Editorial service

- Swift Peer Review

- Reprints availability

- E-prints Service

- Manuscript Podcast for convenient understanding

- Global attainment for your research

- Manuscript accessibility in different formats

( Pdf, E-pub, Full Text, Audio)

- Unceasing customer service

Track the below URL for one-step submission https://juniperpublishers.com/online-submission.php 